\title{
ORIGINAL ARTICLE Cannabidiol is a partial agonist at dopamine D2High receptors, predicting its antipsychotic clinical dose
}

P Seeman ${ }^{1,2}$

Although all current antipsychotics act by interfering with the action of dopamine at dopamine D2 receptors, two recent reports showed that 800 to $1000 \mathrm{mg}$ of cannabidiol per day alleviated the signs and symptoms of schizophrenia, although cannabidiol is not known to act on dopamine receptors. Because these recent clinical findings may indicate an important exception to the general rule that all antipsychotics interfere with dopamine at dopamine D2 receptors, the present study examined whether cannabidiol acted directly on D2 receptors, using tritiated domperidone to label rat brain striatal D2 receptors. It was found that cannabidiol inhibited the binding of radio-domperidone with dissociation constants of $11 \mathrm{~nm}$ at dopamine D2High receptors and $2800 \mathrm{~nm}$ at dopamine D2Low receptors, in the same biphasic manner as a dopamine partial agonist antipsychotic drug such as aripiprazole. The clinical doses of cannabidiol are sufficient to occupy the functional D2High sites. it is concluded that the dopamine partial agonist action of cannabidiol may account for its clinical antipsychotic effects.

Translational Psychiatry (2016) 6, e920; doi:10.1038/tp.2016.195; published online 18 October 2016

\section{INTRODUCTION}

Although currently used antipsychotics for schizophrenia all interfere with the neurotransmission of dopamine, ${ }^{1}$ a report by Leweke et al. $^{2}$ showed that cannabidiol at $800 \mathrm{mg} /$ day was as clinically effective as amisulpride in alleviating the signs and symptoms of schizophrenia. In addition, a recent report by $P$. McGuire et al. ${ }^{3}$ found that $1000 \mathrm{mg}$ per day cannabidiol added to the ongoing antipsychotic treatment significantly improved schizophrenia in a study on 88 patients. Because there are no known reports of cannabidiol acting directly on dopamine D2 receptors, the important findings by Leweke et $a l^{2}$ and McGuire et al. $^{3}$ may indicate that cannabidiol is the first apparent exception to the general rule that all antipsychotics either block or interfere with dopamine at brain dopamine D2 receptors. ${ }^{4,5}$

In fact, McGuire et al. ${ }^{3}$ went so far as to state that the antipsychotic target for cannabidiol was not dopaminergic. Furthermore, the report by Leweke et $a .^{2}$ did not attribute the antipsychotic action of cannabidiol to any particular set of receptors in the brain. For example, it is possible that cannabidiol may act on one or more types of receptors to exert its clinical action. Such possible targets include fatty acid amide hydrolase, serotonin-1 receptors, GPR55 receptors and transient potential vanilloid-1 receptors. ${ }^{6-8}$

Cannabidiol is an active cannabinoid found in high concentration in the cannabis plant (up to $40 \%$ in the extract). Cannabidiol has many possible uses in a variety of medical illnesses, especially in certain types of epilepsy and possibly in treating psychosis. ${ }^{9}$

Although dopamine D2 receptors are a main common target for antipsychotic drugs, it was essential, therefore, for this present study to examine whether cannabidiol had any direct action on dopamine D2 receptors that might account for the clinical antipsychotic effects observed by McGuire et $a l^{3}$ and Leweke et al. ${ }^{2}$ Such an investigation was considered essential in order to test the basis for the commonly known dopamine hypothesis of psychosis, ${ }^{5}$ especially as it is known that the potent cannabinoids HU210 and Win 55,212-2 cause behavioral dopamine supersensitivity and elevated D2High receptors. ${ }^{5}$ That is, should there be no effect of cannabidiol on dopamine D2 receptors, despite having a clinical antipsychotic action, the dopamine hypothesis underlying psychosis would need to be modified.

\section{MATERIALS AND METHODS}

Tissue preparation

Rat striatal tissues were used as a source of dopamine D2 receptors. The rat striata were from carbon-dioxide-killed Sprague-Dawley rats or from frozen rat brains (Pel-Freez Biologicals, Rogers, AR, USA). The brain (stored at $-70^{\circ}$ ) was partly thawed and the striata removed. The striata were homogenized in buffer ( $4 \mathrm{mg}$ frozen tissue per $\mathrm{ml}$ buffer), using a teflonglass homogenizer (with the piston rotating at 500 r.p.m.) and 10 up-anddown strokes of the glass container. The buffer contained $50 \mathrm{~mm}$ Tris-HC1 $\left(\mathrm{pH} 7.4\right.$ at $\left.20^{\circ} \mathrm{C}\right), 1 \mathrm{~mm}$ EDTA, $5 \mathrm{~mm} \mathrm{KCl}, 1.5 \mathrm{~mm} \mathrm{CaCl}{ }_{2}, 4 \mathrm{~mm} \mathrm{MgC1}{ }_{2}$ and $120 \mathrm{~mm} \mathrm{NaCl}$. The homogenate was not washed, centrifuged or preincubated because our previous work found that $30-50 \%$ of the D2 receptors were lost by these procedures. ${ }^{10}$

\section{Cannabidiol/ $\left[{ }^{3} \mathrm{H}\right]$ domperidone competition}

The dopamine D2 receptors in the rat striatal tissue were measured with $\left[{ }^{3} \mathrm{H}\right]$ domperidone (2 to $3 \mathrm{~nm}$ final concentration in the incubation tube; custom-synthesized as [phenyl- ${ }^{3} \mathrm{H}(\mathrm{N})$ ]domperidone; $41.4 \mathrm{Ci} \mathrm{mmol}^{-1}$; made by Moravek Biochemicals and Radiochemicals, Brea, CA, USA). Each incubation tube $(12 \times 75 \mathrm{~mm}$, glass) received, in the following order, $0.5 \mathrm{ml}$ buffer (with or without a final concentration of $10 \mu \mathrm{m} S$-sulpiride to define nonspecific binding to the dopamine D2 receptors; and with or without $10 \mu \mathrm{m}$ guanilylimidodiphosphate), $0.25 \mathrm{ml}\left[{ }^{3} \mathrm{H}\right]$ domperidone, and $0.25 \mathrm{ml}$ of tissue homogenate. The tubes (total volume of $1 \mathrm{ml}$ contents) were incubated for $2 \mathrm{~h}$ at room temperature $\left(20^{\circ}\right)$, after which the incubates were filtered using a 12-well cell harvester (Titertek, Skatron, Lier, Norway) and buffer-presoaked glass fiber filter mats (Whatman GF/C). After filtering

${ }^{1}$ Department of Psychiatry, University of Toronto, Toronto, ON, Canada and ${ }^{2}$ Department of Pharmacology, University of Toronto, Toronto, ON, Canada. Correspondence: Professor P Seeman, Department of Psychiatry, University of Toronto, 260 Heath Street West, Toronto, ON, Canada M5P 3L6. 


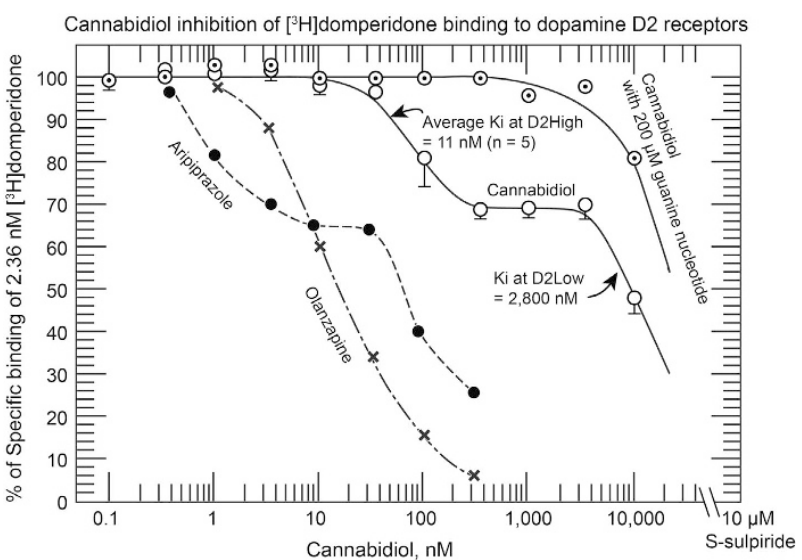

Figure 1. In a biphasic manner, cannabidiol inhibited the binding of $\left[{ }^{3} \mathrm{H}\right]$ domperidone to dopamine D2 receptors in rat brain homogenized striata, similar to the biphasic pattern for other dopamine agonists and the partial dopamine agonist antipsychotic aripiprazole. The earlier published data for aripiprazole ${ }^{12}$ are redrawn here to show the similarity to cannabidiol. Olanzapine (redrawn from Seeman et al. $^{13}$ ) and all other antipsychotic antagonists do not reveal a biphasic pattern when using any antagonist radioligand for D2.

the incubate, the filter mat was rinsed with buffer for $15 \mathrm{~s}(7.5 \mathrm{ml}$ buffer). The filters were pushed out and placed in scintillation minivials $(7 \mathrm{ml}$, $16 \times 54 \mathrm{~mm}$; Valley Container, Bridgeport, CT, USA). The minivials received $4 \mathrm{ml}$ each of scintillant (Research Products International, Mount Prospect, IL, USA), and were monitored $6 \mathrm{~h}$ later for tritium in a Beckman LS5000TA scintillation spectrometer (Beckman, Chicago, IL, USA) at 55\% efficiency. The specific binding of $\left[{ }^{3} \mathrm{H}\right]$ domperidone was defined as total binding minus that in the presence of $10 \mu \mathrm{m} \mathrm{S}$-sulpiride.

\section{Analysis and statistics}

The competition data were analyzed using a program that provided statistical criteria to judge whether a two-site fit was better than a one-site fit, or whether a three-site fit was better than a two-site fit, using the GraphPad Prism method (GraphPad Software, La Jolla, CA, USA). A total of five completely independent experiments were done. The values for percent inhibition were averaged for each concentration of cannabidiol and the s.e. obtained.

Independently, the Cheng-Prusoff equation (Cheng and Prusoff ${ }^{11}$ ) was also used to derive the dissociation constants ( $K_{\mathrm{i}}$ values) of the compound from the concentration that inhibited $50 \%$ of the high-affinity component $\left(\mathrm{IC}_{50 \%}\right)$ or $50 \%$ of the low-affinity component for $\left[{ }^{3} \mathrm{H}\right]$ domperidone, as indicated in the results. The form of the Cheng-Prusoff equation used was $K_{\mathrm{i}}=I \mathrm{I}_{50} \% /\left(1+C^{*} / K_{\mathrm{d}}\right)$, where $C^{*}$ was the final concentration of the radioligand and $K_{\mathrm{d}}$ was the dissociation constant of $\left.{ }^{3} \mathrm{H}\right]$ domperidone $\left(K_{d}=0.5 \mathrm{~nm}\right)$, as determined directly by the saturation binding of $\left[{ }^{3} \mathrm{H}\right]$ domperidone (that is, Scatchard plot) to the striatal homogenate. Reagents and compounds were obtained from commercial sources (Sigma-Aldrich, St. Louis, MO, USA).

\section{RESULTS}

The competition between cannabidiol and $\left[{ }^{3} \mathrm{H}\right]$ domperidone at brain dopamine D2 receptors was tested over a range of cannabidiol concentrations from 0.1 to $10,000 \mathrm{~nm}$, using $\left[{ }^{3} \mathrm{H}\right]$ domperidone concentrations (usually $2.3 \mathrm{~nm}$ ) that occupied about $82 \%$ of the D2 receptors. (On the basis of the fact that $\left[{ }^{3} \mathrm{H}\right]$ domperidone had a $K_{\mathrm{d}}$ of about $0.5 \mathrm{~nm}$ for the D2 receptor, the fraction of D2 receptors occupied was $C /\left(C+K_{\mathrm{d}}\right)$ or $2.3 \mathrm{~nm} /(2.3 \mathrm{~nm}$ $+0.5 \mathrm{~nm})$ ).

The results for the competition are in Figure 1. The data in Figure 1 show that cannabidiol had a biphasic action in competing against $\left[{ }^{3} \mathrm{H}\right]$ domperidone at the brain dopamine D2 receptors. Cannabidiol inhibited the binding of $\left[{ }^{3} \mathrm{H}\right]$ domperidone at the high-affinity component (at dopamine D2High receptors) with
$50 \%$ inhibition occurring at $66 \mathrm{~nm}(n=5$; s.e. $20 \mathrm{~nm})$. In addition, cannabidiol inhibited the low-affinity component of binding (at dopamine D2Low receptors) with $50 \%$ inhibition occurring at $2800 \mathrm{~nm}(n=5)$.

Using the Cheng-Prusoff relation, ${ }^{11}$ the cannabidiol dissociation constants ( $K_{\mathrm{i}}$ values) were $11 \mathrm{~nm}$ at D2High and $2800 \mathrm{~nm}$ at D2Low.

Furthermore, in the presence of $200 \mu \mathrm{m}$ guanilylimidodiphosphate, the binding of $\left[{ }^{3} \mathrm{H}\right]$ domperidone to the high-affinity site (at D2High receptors) was completely abolished. All the dopamine D2High receptors had converted to their D2Low state in the presence of the guanine nucleotide.

In contrast to the reproducible biphasic pattern of cannabidiol competition versus the binding of $\left[{ }^{3} \mathrm{H}\right]$ domperidone, there was no such biphasic competition when cannabidiol competed against the binding of $\left[{ }^{3} \mathrm{H}\right]$ raclopride (data not shown). In fact, cannabidiol inhibited the binding of $\left[{ }^{3} \mathrm{H}\right]$ raclopride with only a single dissociation constant of $4900 \mathrm{~nm}$ at the dopamine D2Low receptors (with an $\mathrm{IC}_{50} \%$ concentration of $9000 \mathrm{~nm}$ ). Such a phenomenon was also previously seen with dopamine, which competed in a biphasic manner versus $\left[{ }^{3} \mathrm{H}\right]$ domperidone but in a monophasic manner at D2Low receptors when using $\left[{ }^{3} \mathrm{H}\right]$ raclopride. $^{14}$

\section{DISCUSSION}

The data in Figure 1 clearly show that cannabidiol inhibited the binding of $\left[{ }^{3} \mathrm{H}\right]$ domperidone in two phases, corresponding to dopamine D2High and D2Low dopamine receptors. This biphasic pattern only occurs with dopamine agonists, as consistently found with hallucinogens ${ }^{15}$ and the commonly used anti-Parkinson agonists. $^{16}$

Such a biphasic pattern does not occur with any of the antipsychotics, except for aripiprazole, ${ }^{12}$ which is a partial agonist (see Figure 1, where the previously published data for aripiprazole $^{12}$ are redrawn to show the similarity to the effect of cannabidiol; olanzapine and all other antipsychotic antagonists do not reveal the biphasic pattern. $)^{13}$ Brexpiprazole and cariprazine are relatively new compounds and have not yet been examined in this assay.

Therefore, the biphasic pattern of cannabidiol in inhibiting the binding of $\left[{ }^{3} \mathrm{H}\right]$ domperidone, in exactly the same way as aripiprazole, indicates that cannabidiol may act clinically as a partial agonist at the dopamine D2 receptors, similar to the clinical antipsychotic action of aripiprazole.

The present data for cannabidiol may help explain some effects of cannabidiol that has actions similar to atypical antipsychotic drugs. $^{17-19}$

Such a partial agonist-type action at a G-protein-linked receptor has been reported ${ }^{20}$ for delta9-tetrahydrocannabinol at the rat cerebellar cannabinoid receptor but not for cannabidiol. In fact, it was reported ${ }^{20}$ that cannabidiol behaved as an antagonist in the micromolar concentration range.

The present data for cannabidiol acting at the dopamine D2High sites with a dissociation constant of $11 \mathrm{~nm}$ may well account for the antipsychotic effects reported by McGuire et al. ${ }^{3}$ and Leweke et al., ${ }^{2}$ because the dopamine D2High receptors are considered to be the functional dopamine D2 receptor sites. ${ }^{21,22}$ More specifically, the clinical daily doses ${ }^{2,3}$ of $800 \mathrm{mg}$ and $1000 \mathrm{mg}$ cannabidiol would adequately occupy the D2High receptors in vivo. For example, a daily dose of $800 \mathrm{mg}$ cannabidiol would result in an extracellular free concentration level in humans of the order of $600 \mathrm{~nm}$, after allowing for at least $99 \%$ of the cannabidiol to be bound to plasma proteins. ${ }^{23}$

In addition, considering that cannabidiol has a $K_{\mathrm{i}}$ value of $11 \mathrm{~nm}$ at D2High, as compared with $0.2 \mathrm{~nm}$ for aripiprazole, a possible clinical antipsychotic dose for cannabidiol would be of the order of 55 -fold higher than aripiprazole. Because the antipsychotic dose of aripiprazole is between 10 and $20 \mathrm{mg}$ per day, the 
antipsychotic dose for cannabidiol would be 550 to $1100 \mathrm{mg}$ per day, which is the dose range that Leweke et $a l^{2}$ and that McGuire ${ }^{3}$ used for patients with schizophrenia.

It may be argued that the present in vitro effect of cannabidiol may occur by the action of cannabidiol on the striatal cannabinoid CB1 receptors that are colocalized as heteromers with dopamine D2 receptors, ${ }^{24,25}$ thereby indirectly influencing the binding of $\left[{ }^{3} \mathrm{H}\right]$ domperidone at the D2 receptors. However, the following important points indicate that such an indirect action through CB1/D2 heteromers is unlikely.

Cannabidiol concentrations between 35 and $350 \mathrm{~nm}$ effectively inhibited the binding of $\left[{ }^{3} \mathrm{H}\right]$ domperidone to the D2High site (Figure 1). However, the dissociation constant of cannabidiol at the brain cannabinoid CB1 receptors is between 4350 and $27542 \mathrm{~nm}^{9}$ indicating that the CB1 receptors would not be significantly affected by cannabidiol concentrations between 35 and $350 \mathrm{~nm}$.

Moreover, although the expression of CB1/D2 heteromers is found in 30 to $60 \%$ of monkey striatal neurons, ${ }^{26}$ only a very small non-significant influence was found for the alteration of dopamine competition of the D2 ligand [3H]YM-09151-02 on caudate nucleus membranes by the CB1 agonist CP55940, thereby indicating a very weak interaction between $\mathrm{CB} 1$ and D2 receptors. $^{26}$

It is not known why cannabidiol inhibited the binding of $\left[{ }^{3} \mathrm{H}\right]$ domperidone in a biphasic manner at D2High and D2Low receptor sites (Figure 1), yet inhibited the binding in a monophasic manner at only D2Low when using $\left[{ }^{3} \mathrm{H}\right]$ raclopride (data not shown). A similar situation occurred with dopamine, ${ }^{14}$ as mentioned above. It is possible that the two different $\left[{ }^{3} \mathrm{H}\right]$ ligands have a different mode of attachment to the dopamine D2 receptor, based on the fact that domperidone has a pKa of 7.9, whereas raclopride has a pKa of 8.97, resulting in a different proportion of charged and uncharged species of the two ligands, where the charged nitrogen atom of domperidone and raclopride is expected to be the main point of attachment. The fact that $\left[{ }^{3} \mathrm{H}\right]$ raclopride was not competed by cannabidiol at $\mathrm{D} 2 \mathrm{High}$ precludes the ready measurement of cannabidiol versus the binding of $\left[{ }^{11} \mathrm{C}\right]$ raclopride in possible studies in humans.

The apparent partial agonist action of cannabidiol in vitro in the present work may possibly account for some of the clinical sideeffects of cannabidiol such as somnolence, diarrhea, decreased appetite and fatigue. ${ }^{27}$ Moreover, because it is well known that the partial dopamine agonist aripipazole can sometimes elicit psychotic signs and symptoms in patients, ${ }^{28}$ it is entirely possible that long-term use of marijuana can lead to an accumulation of the cannabidiol partial agonist in some individuals and cause a psychotic episode. This is unlikely, however, because cannabidiol has been reported to protect against the effects of tetrahydrocannabinol. ${ }^{29,30}$

\section{CONFLICT OF INTEREST}

The author declare no conflict of interest.

\section{ACKNOWLEDGMENTS}

I thank Dr H.-C. Guan for excellent technical assistance and Dr Bertha K. Madras and Dr Harold Kalant for helpful science advice. This work was supported by Janet Marsh Frosst, David Medland, Pamela and Desmond O'Rorke, in memory of John William Medland, and by the estate of the late Dr Karolina Jus.

\section{REFERENCES}

1 Miyamoto S, Miyake N, Jarskog LF, Fleischhacker WW, Lieberman JA. Pharmacological treatment of schizophrenia: a critical review of the pharmacology and clinical effects of current and future therapeutic agents. Mol Psychiatry 2012; 17: $1206-1227$
2 Leweke FM, Piomelli D, Pahlisch F, Muhl D, Gerth CW, Hoyer C et al. Cannabidiol enhances anandamide signaling and alleviates psychotic symptoms of schizophrenia. Transl Psychiatry 2012; 2: e94.

3 Davenport L Cannabis compound may augment antipsychotic meds. Available at www.medscape.com/viewarticle/862312 (accessed on 9 May 2016).

4 Seeman P, Chau-Wong M, Tedesco J, Wong K. Brain receptors for antipsychotic drugs and dopamine: Direct binding assays. Proc Natl Acad Sci USA 1975; 72: 4376-4380.

5 Seeman P. All roads to schizophrenia lead to dopamine supersensitivity and elevated dopamine D2 ${ }^{\text {High }}$ receptors. CNS Neurosci Ther 2011; 17: 118-132.

6 Long LE, Malone DT, Taylor DA. Cannabidiol reverses MK-801-induced disruption of prepulse inhibition in mice. Neuropsychopharmacology 2006; 31: 795-803.

7 Gomes FV, Llorente R, Del Bel EA, Viveros MP, López-Gallardo M, Guimarães FS. Decreased glial reactivity could be involved in the antipsychotic-like effect of cannabidiol. Schizophr Res 2015; 164: 155-163.

8 Campos AC, Moreira FA, Gomes FV, Del Bel EA, Guimarães FS. Multiple mechanisms involved in the large-spectrum therapeutic potential of cannabidiol in psychiatric disorders. Philos Trans R Soc Lond B Biol Sci 2012; 367: 3364-3378.

9 Pertwee RG. The diverse CB1 and CB2 receptor pharmacology of three plant cannabinoids: delta9-tetrahydrocannabinol, cannabidiol and delta9tetrahydrocannabivarin. Br J Pharmacol 2008; 153: 199-215.

10 Seeman P, Ulpian C, Wreggett KA, Wells JW. Dopamine receptor parameters detected by $[3 \mathrm{H}]$ spiperone depend on tissue concentration: analysis and examples. J Neurochem 1984; 43: 221-235.

11 Cheng Y, Prusoff WH. Relationship between the inhibition constant (Ki) and the concentration of inhibitor which causes 50 per cent inhibition (IC50) of an enzymatic reaction. Biochem Pharmacol 1973; 22: 3099-3108.

12 Seeman P. Dopamine D2 ${ }^{\text {High }}$ receptors moderately elevated by bifeprunox and aripiprazole. Synapse 2008; 62: 902-908.

13 Seeman $P$, Kapur S. Olanzapine binding to dopamine receptors in vitro and in vivoln: Tran PV, Bymaster F, Tye N, Herrera J, Breier A, Tollefson G (eds). Olanzapine (Zyprexa)—A Novel Antipsychotic. Eli Lilly, Lippincott Williams \& Wilkins: Philadelphia, PA, USA, 2000, 3-24.

14 Seeman $\mathrm{P}$, Tallerico T, Ko F. Dopamine displaces $\left[{ }^{3} \mathrm{H}\right]$ domperidone from highaffinity sites of the dopamine D2 receptor, but not $\left[{ }^{3} \mathrm{H}\right]$ raclopride or $\left[{ }^{3} \mathrm{H}\right]$ spiperone in isotonic medium: Implications for human positron emission tomography. Synapse 2003; 49: 209-215.

15 Seeman P, Guan H-C, Hirbec H. Dopamine D2 ${ }^{\text {High }}$ receptors stimulated by phencyclidines, LSD, salvinorin A, and modafinil. Synapse 2009; 63: 698-704.

16 Seeman P. Anti-Parkinson therapeutic potencies correlate with their affinities for dopamine D2 ${ }^{\text {High }}$ receptors. Synapse 2007; 61: 1013-1018.

17 Zuardi AW, Rodrigues JA, Cunha JM. Effects of cannabidiol in animal models predictive of antipsychotic activity. Psychopharmacology (Berl) 1991; 104: 260-264.

18 Moreira FA, Guimarães FS. Cannabidiol inhibits the hyperlocomotion induced by psychotomimetic drugs in mice. Eur J Pharmacol 2005; 512: 199-205.

19 Guimarães VM, Zuardi AW, Del Bel EA, Guimarães FS. Cannabidiol increases Fos expression in the nucleus accumbens but not in the dorsal striatum. Life Sci 2004; 75: 633-638.

20 Petitet F, Jeantaud B, Reibaud M, Imperato A, Dubroeucq MC. Complex pharmacology of natural cannabinoids: evidence for partial agonist activity of delta9tetrahydrocannabinol and antagonist activity of cannabidiol on rat brain cannabinoid receptors. Life Sci 1998; 63: PL1-PL6.

21 George SR, Watanabe M, Di Paolo T, Falardeau P, Labrie F, Seeman P. The functional state of the dopamine receptor in the anterior pituitary is in the highaffinity form. Endocrinology 1985; 117: 690-697.

22 McDonald WM, Sibley DR, Kilpatrick BF, Caron MG. Dopaminergic inhibition of adenylate cyclase correlates with high affinity agonist binding to anterior pituitary D2 dopamine receptors. Mol Cell Endocrinol 1984; 36: 201-209.

23 Grotenhermen F. Pharmacokinetics and pharmacodynamics of cannabinoids. Clin Pharmacokinet 2003; 42: 327-360.

24 Marcellino D, Carriba P, Filip M, Borgkvist A, Frankowska M, Bellido I. Antagonistic cannabinoid CB1/dopamine D2 receptor interactions in striatal CB1/D2 heteromers. A combined neurochemical and behavioral analysis. Neuropharmacology 2008; 54: 815-823.

25 Ferré S, Goldberg SR, Lluis C, Franco R. Looking for the role of cannabinoid receptor heteromers in striatal function. Neuropharmacology 2009; 56(Suppl 1): 226-234.

26 Bonaventura J, Rico AJ, Moreno E, Sierra S, Sánchez M, Luquin N et al. L-DOPAtreatment in primates disrupts the expression of $A(2 A)$ adenosine- $C B(1)$ cannabinoid-D(2) dopamine receptor heteromers in the caudate nucleus. Neuropharmacology 2014; 79: 90-100. 
27 GW Pharmaceuticals. GW Pharmaceuticals announces positive phase 3 pivotal study results for Epidiolex (cannabidiol) (accessed on 8 May 2016).

28 Takase M, Kanahara N, Oda Y, Kimura H, Watanabe H, lyo M. Dopamine supersensitivity psychosis and dopamine partial agonist: a retrospective survey of failure of switching to aripiprazole in schizophrenia. J Psychopharmacol 2015; 29: 383-389.

29 Morgan CJ, Curran HV. Effects of cannabidiol on schizophrenia-like symptoms in people who use cannabis. Br J Psychiatry 2008; 192: 306-307.

30 Di Forti M, Morgan C, Dazzan P, Pariante C, Mondelli V, Marques TR et al. Highpotency cannabis and the risk of psychosis. Br J Psychiatry 2009; 195: 488-491.

(c) (i)

This work is licensed under a Creative Commons Attribution 4.0 International License. The images or other third party material in this article are included in the article's Creative Commons license, unless indicated otherwise in the credit line; if the material is not included under the Creative Commons license, users will need to obtain permission from the license holder to reproduce the material. To view a copy of this license, visit http://creativecommons.org/licenses/ by/4.0/

(c) The Author(s) 2016 